\title{
AN ANALYSIS OF STUDENTS READING COMPREHENSION ON RECOUNT TEXT AT SMK DHARMA BAKTI 1 MEDAN
}

\author{
Febri Nila Rosaria Hutagalung ${ }^{1}$, Dervine Hutagalung ${ }^{2}$, Dinaria Veronika \\ Simanjuntak ${ }^{3}$, Putri Delima Yanti Tampubolon ${ }^{4}$ \\ English Education Department, University of Prima Indonesia \\ Email : febrihutagalung83@gmail.com ${ }^{1}$, dervinehutagalung@gmail.com 2 , \\ dinariasimanjuntak@gmail.com $^{3}$, putridelimat1009@gmail.com $^{4}$
}

\begin{abstract}
This research was conducted to describe the students' ability to read and understand the Recount Text. The purpose of this study was to analyze the students' ability in understanding the Recount Text. This research used descriptive qualitative method. This research was conducted at SMK Dharma Bakti 1 Medan. The sample of this research was 17 students of class 10 TKJ. This study used a reading test and interview instruments. Based on the research results, it was found that the highest score of students was 73.00 and the lowest score of students was 6.00. The low score of students caused by the lack of understanding of students in reading recount text and limited vocabulary of students.
\end{abstract}

Keywords: Students' analysis, reading comprehension, recount text

Abstrak. Penelitian ini dilakukan untuk Mendeskripsikan kemampuan siswa dalam membaca dan memahami Teks Recount. Tujuan penelitian ini adalah untuk menganalisis kemampuan siswa dalam memahami Teks Recount. Penelitian ini menggunakan metode kualitatif deskriptif. Penelitian ini dilakukan di SMK Dharma Bakti 1 Medan. Sampel penelitian ini sebanyak 17 siswa kelas X-TKJ. Penelitian ini menggunakan instrumen tes membaca dan wawancara. Berdasarkan hasil penelitian, ditemukan skor tertinggi siswa adalah 73,00 dan skor terendah siswa adalah 6,00. Rendahnya nilai siswa disebabkan oleh kurangnya pemahaman siswa dalam membaca teks recount serta kosakata yang dimiliki siswa terbatas.

kata kunci : Analisis siswa, pemahaman membaca, teks recount

\section{INTRODUCTION}

Learning English there are 4 skills that are important to master, namely; listening, speaking, reading and writing. Reading is one of the most important skills a person has in learning, because reading can educate, increase knowledge and insight. Reading is a process of understanding the reading text which aims to deduce the meaning contain in the reading text. Many people wonder why reading skills are more important than other skills? Reading is more important because reading is able to develop thoughts. Reading will open up opportunities to absorb a lot of useful knowledge of the reading text. Therefore, reading skills are taught from childhood. Students must have reading skills in the teaching and learning process.
According to Moreillon in Hana Junika, (2018:7) "state that reading is making meaning from print and from visual information. But reading is not simple. Reading is an active process that requires a great deal of practice and skill". According to Harmer in Yuliana (2018:13) "reading is an exercise dominated by the eyes and brain. The eyes receive the messages from what we read and the brain has to significance messages and make us understand what the messages about. In reading, students not only read, but also understand what they are reading. So, they can get the knowledge and enjoy what they read". In addition, Walker in Yuliana (2018:14) "defines that reading is an active process in which readers shift between sources of information, elaborate meaning. 
Reading may be one of the single most important skills that a person can possibly acquire. It is generally taught at a very young age, beginning before kindergarten. The national reading panel has stated that there are five specific practices that teachers should be using when teaching children to read or when helping them improve their reading skills. The process of understanding the text is called reading comprehension. In fact, reading is not a simple process, not just open the book, read the book and then close the book, but the reader must understand what the researcher tells about".

Reading comprehension is the ability to take conclusions from a write based on several components depending on the reader's need. Reading comprehension also include aspects that are capable of creating its own meaning from what the reader is looking for, including the reader's purpose of looking for real information and then transfer the meaning of the reading to others with their own understanding. So that reading comprehension is important for students to help with reading. According to Klinger, et al in Yuliana (2018:14) "says that reading comprehension is a multi component, highly complex process that involve much interaction between readers and what they bring to the text as well as variables related to the text itself. In other words, the reader and the researcher become one mind and the concepts are translated from one person to another. Reading comprehension involves at least two people: the reader and the researcher. The process of comprehending involves decoding the researcher's words and then the reader uses his/her background knowledge to construct the researcher's messages".

According to Zhi-Hong in Yuliana (2018:15) "says that reading comprehension is the construction of meaning from printed or written message. It means that the reader constructs the meaning of a text through reading the text. Understanding the meaning of the text or having a good comprehension in reading is a factor to be successful. He adds that there are many factors influencing reading comprehension such as reader's characteristics, the nature of reading materials, and reading tasks, etc".

According to King and Stanley in Yuliana (2018:15) "state that there are five components that may help the students to read carefully. First is finding factual information. Finding factual information requires readers to scan specific details. The factual information, questions generally appear with WH question word. Second is finding main ideas. Finding the ideas is very important because it's not only helping to understand the paragraph, but also helps to remember the content later. Third is meaning of difficult word. It means that the readers can develop his/her guessing ability to the word which is not familiar with him or her, by relating the close meaning of unfamiliar words to the text. Forth is identifying references. It would be boring to have and repeat the same word or phrase in every paragraph of a text. To avoid the repetition word, it can be used references of the word. References words are very frequently in terms of pronoun such as: it, she, he, this, etc. Fifth is finding restatement. The restatement is the way to say something again in a different way, but still has the same meaning. It is intended to measure readers' ability in analyzing the relationship of idea with in a single sentence".

There are several types of text in English, namely: narrative text, description text, report text, exposition text, explanation text, discussion text, procedure text, review text, spoof, anecdote, news item, and recount text. But here the writers discuss the recount text. Recount text is a retelling of activities, events and experiences of a person that happened in the past. Recount text is different from narrative text where in narrative text there are orientation, conflict and problem solving. Recount text tell experiences or events in a simple form without drama or conflict in the past. According to Anderson in Yuliana (2018:40) "suggest that the recount is a text which tells about events happening in the past in a sequence of time. The purpose of the text is to tell the audience about what happened in the past and when it happened". 
Previous researches conducted by Yuliana (2018), "She found that the students' ability in reading and comprehending of recount textat SMP An Nur Pekan Baru. There were 4 students who got very good scores, there were 20 students who got good scores and 7 students who got fair scores. The mean score of the whole students' scores was 77.98. So could be concluded that ability in reading and comprehending recount text at SMP An Nur Pekan Baru was good".

Previous researches conducted by Najmatul Fahli, Mahdum, Fakhri Ras (2015), "They found that the students' ability in comprehending recount text at SMP Muhammadiyah 1 Pekan Baru was in poor level. It showed that the students' ability in comprehending recount text was quite difficult to understand by students so the students got poor scores. The average score of the whole students' scores was 50-59".

Previous researches conducted by Hana Junika (2018), "she investigated the an analysis of student reading comprehension in recount text of Barrett taxonomy at the eighth grade of SMP Negeri 4 Siak Hulu. She found that the students reading comprehension of recount text at state Junior High School 4 Siak Hulu are categorized into less level and the must difficult taxonomy of reading comprehension for the students is taxonomy 4 (appreciation) the students' reading comprehension is categorized into a less level at score 54,9".

In fact, not all students of SMK Dharma Bakti 1 Medan are successful in reading comprehension. They are still low in reading, especially in recount text. Based on preliminary research during PPL/KKL from August to September, the writers observe students' reading comprehension.

Various efforts have been made by school and teacher to improve students' reading comprehension such as, facilitating schools like the preparing books, providing reinforcement, approaches, motivation, using variations in teaching, using appropriate learning media,altering patterns of interaction and with the purpose of creating a pleasant learning and using an effective and conductive learning models in certain subject matter.

If the problem is not resolved, it will be appear the impact for students and also for the next graduation and students will face several obstacles in continuing with other materials because all materials conduct each other.

In this research, the researchers discuss one type of reading comprehension namely, recount text which retelling eventsand experiences that happened in the past. Actually, recount text aims to entertain or provide information to the readers.

In this research, the researchers use reading comprehension to teach the students about recount text. Reading comprehension helps students to get something when they first read the text. For reading comprehension, the teachers guide students how to read and think like effective readers. Especially, in analytical reading, an approach is always need in order to achieve the purpose of reading

\section{Problems of Study}

1. How is the understanding of students in reading recount text at SMK Dharma Bakti 1 Medan?

2. What difficulties are students face in taking reading comprehension test?

\section{Objectives of Study}

1. To find out the reading comprehension of students at SMK Dharma Bakti 1 Medan.

2. To find out the difficulties faced by students in doing the reading comprehension test.

\section{Scope of the Study}

To find out the students' ability to read and understand recount text at SMK Dharma Bakti 1 Medan. This study take 17 students from class $\mathrm{X}$. The researchers use recount text by providing text and questions to students.

\section{Significances of the Study}

The results of this study are expected to be of benefit to the following individual or institution below:

1. For students: It can improve the students' ability in reading and comprehending recount text. 
2. For teachers: Provides useful input information that is useful in improving the quality of learning in the school.

3. For further researchers: As a reference for further research on the teaching and learning process of reading in recount text.

\section{METHOD}

The researchers applied descriptive qualitative method in this study. Descriptive research was designed to get information about the current status of the phenomena. It was directed at determining the nature of a situation as it exists of the study. According to Surakhmadin Yuliana (2018:44) "stated that descriptive method is a kind of research method employing the technique of searching, collecting, classifying, analyzing the data, interpreting them and finally describing the conclusion". Consequently, the goal of this research to analyze the students' ability of reading comprehension on recount text at SMK Dharma Bakti 1 Medan.

In this part, the writers observed in this study was about what difficulties that students faced of reading comprehension on a recount text by grade $\mathrm{X}$ students of SMK Dharma Bakti 1 Medan.

\section{Location and Time of Research}

This research was conducted at SMK Dharma Bakti 1 Medan which is located at Jl. Letjen Jamin Ginting km.8 Padang Bulan. The researchers only wanted to analyze what difficulties did students faced to understand reading comprehension on recount text.

\section{The Subject of Research}

The subject of this research were students at SMK Dharma Bakti 1 Medan in academic year 2020-2021. The researchers took a sample of 17 students from X TKJ .

\section{Instrument of Research}

The research instrument was a reading test. The type of reading test that used objective test. From this research, researcher used reading test to collect the data. This section the researchers used data techniques, namely:

\section{Test}

The writers were provided an online test to answer according to the writers' instruction. After they answered the test, the writers checked and measured the students' test results (Score).

\section{Interview}

The writers asked whether the students understood or not the material given by the writers. The writers made note that supplies the student's test scores.

\section{Technique of Collecting Data}

The researchers used a multiplechoice test to collect the data. The number of the test item were 15 questions. The test consists of 3 short recount texts. In each text had 5 questions. The time allocated for doing test were 60 minutes. In this section the researchers collected students' answers. The researchers gave instruction to complete the test correctly and clearly.

\section{Technique of Analyzing Data}

$$
\text { Score }=\frac{100}{1} \times \text { CA }
$$

To determine the level of students reading compherension, the researchers used percentage grade based to classification in the table following:

\begin{tabular}{|c|c|}
\hline Score & Classification \\
\hline $85-100$ & Very Good \\
\hline $75-84$ & Good \\
\hline $65-74$ & Fair \\
\hline$<65$ & Poor \\
\hline
\end{tabular}

\section{RESULT AND DISCUSSION}

Before analyzing the data, the researchers found out the answer to questions related to students' ability to understand reading comprehension of recount text for X TKJ at SMK Dharma Bakti 1 Medan. The researchers gave 15 questions in multiple choice form and conducted online interview. In this interview, the researchers asked the students what is the reasons or difficulties that students faced in doing reading comprehension. The interview results are as follows: 
1. The lack of understanding of vocabulary owned by students so that the students had difficulty to answer the questions.

2. Some students said that they had never done the test before, so it was difficult for them.

3. Some students didn't interest to test of recount text so that they did it without translating the text first.

4. Some students had difficult to understand the text because those are several students who translated it word by word.

5. The last, some students didn't know what the meaning of the questions so that they were lazy to do it.

From the results of the interview conducted, the researchers concluded that the difficulty faced by students when answering the comprehension reading test questions was that most students did not master vocabulary so, that it was difficult to translate and understood the text of the reading comprehension.

To addition the interviews, the writers collected the data of the test scores gave to students. So, the tables below of correct answer by the students.

Table 3.1 The Students' Correct Answering of Class X-TKJ

\begin{tabular}{|c|c|c|}
\hline No & $\begin{array}{c}\text { Initial Names of } \\
\text { Students }\end{array}$ & $\begin{array}{c}\text { Correct } \\
\text { Answer }\end{array}$ \\
\hline 1 & PMG & 11 \\
\hline 2 & PS & 9 \\
\hline 3 & DNBK & 8 \\
\hline 4 & FABG & 8 \\
\hline 5 & AP & 7 \\
\hline 6 & TABP & 7 \\
\hline 7 & DJS & 7 \\
\hline 8 & GBLG & 5 \\
\hline 9 & YAM & 5 \\
\hline 10 & YABN & 5 \\
\hline 11 & SPB & 4 \\
\hline 12 & CABB & 4 \\
\hline 13 & DVBK & 4 \\
\hline 14 & ASS & 1 \\
\hline 15 & LDS & 1 \\
\hline 16 & RBG & 1 \\
\hline 17 & RSP & 1 \\
\hline
\end{tabular}

From the data above, the highest answer was obtained by 1 student and the lowest answer were obtained by16 students. The students scores showed in the following table after using the formula.

Where :

$$
\mathrm{S}=\frac{100}{I} \times \mathrm{CA}
$$

$$
\begin{array}{ll}
\mathrm{S} & =\text { The Score } \\
\mathrm{CA} & =\text { Correct Answer } \\
\mathrm{I} & =\text { The Number of Items }
\end{array}
$$

Table 3.2 The Students' Score of Class XTKJ

\begin{tabular}{|c|c|c|c|}
\hline No & $\begin{array}{c}\text { Initial Names } \\
\text { of Students }\end{array}$ & $\begin{array}{c}\text { Correct } \\
\text { Answer }\end{array}$ & Score \\
\hline 1 & PMG & 11 & 73 \\
\hline 2 & PS & 9 & 60 \\
\hline 3 & DNBK & 8 & 53 \\
\hline 4 & FABG & 8 & 53 \\
\hline 5 & AP & 7 & 46 \\
\hline 6 & TABP & 7 & 46 \\
\hline 7 & DJS & 7 & 46 \\
\hline 8 & GBLG & 5 & 33 \\
\hline 9 & YAM & 5 & 33 \\
\hline 10 & YABN & 5 & 33 \\
\hline 11 & SPB & 4 & 26 \\
\hline 12 & CABB & 4 & 26 \\
\hline 13 & DVBK & 4 & 26 \\
\hline 14 & ASS & 1 & 6 \\
\hline 15 & LDS & 1 & 6 \\
\hline 16 & RBG & 1 & 6 \\
\hline 17 & RSP & 1 & 6 \\
\hline
\end{tabular}

From the data above, it could be seen "73" was the student highest score, while " 6 " was the student lowest score. The percentage data of students showed in the following table:

3.3 Table Students Percentage of Class XTKJ

\begin{tabular}{|c|c|c|c|c|}
\hline NO & Score & Level & Frequency & \% \\
\hline 1 & $85-100$ & Very Good & - & - \\
\hline 2 & $75-84$ & Good & - & - \\
\hline 3 & $65-74$ & Fair & 1 & 5,9 \\
\hline 4 & $<65$ & Poor & 16 & 94,1 \\
\hline
\end{tabular}

From the data above, It showed that 1 student categorized as fair and most of the students, namely 16 students, categorized as having less understanding.

From the test results, it could be concluded that in general, the students' ability 
in reading comprehension of the recount text can be categorized as poor.

\section{CONCLUSIONS AND SUGGESTIONS}

The researchers present the conclusion and provide suggestions. These two points as follows:

\section{Conclusion}

Based on research conducted in SMK Dharma Bakti 1 Medan, the researchers found the students' ability in reading and comprehending recount text, where the highest answer was obtained by 1 student who got fair score, and the lowest answer were obtained by 16 students who got poor score. The highest score of the students was 73,00 and the lowest score was 6,00. So it could be concluded that the students' ability in reading and comprehending recount text at SMK Dharma Bakti 1 Medan was poor.

\section{Suggestion}

Based on the data obtained, the researchers propose suggestion, namely:

\section{For Students}

Students had to memorize a lot of vocabulary so that it is not difficult to translate. In addition, students must also improve reading comprehension on a recount text by studying hard and practicing a lot. In this way students expected to be more active and enthusiastic in learning, especially in reading comprehension of the recount text.

\section{For English Teachers}

Researchers expect English teachers to be more active in teaching and evaluating students' abilities in reading comprehension of the recount text, because researchers did not find students who had excellent or good grades. English teachers must pay attention and encourage especially to the majority of students who got bad grades. English teachers must pay attention to student needs and student difficulties to implement good solutions.

\section{REFERENCES}

Anderson, Mark and Kathy Anderson.Text Types in English, (Australia: Mcmillan,1997)
Hana Junika. (2018). An analysis of Students' Reading Comprehension in Recount Text of Barrett Taxonomy at the Eight Grade of SMP Negeri 4 Siak Hulu.

Skripsi Thesis, Universitas Islam Negeri Sultan Syarif Kasim Riau.

Harmer, Jeremy. The Practice of English Language Teaching. Longman Handbooks for Language Teacher, (London: Longman Ninth Impression, 2001)

Hong, Z. (2007). The Effect of Learning Strategies on Reading Comprehension. Sino-US English Teaching 4(4): 15-18.

King, Carroll and Stanley, Nancy. (1989). Building Skill for the TOEFL. Thomas Nelson and Son Ltd

Klinger,etal. (2007).Teaching Reading Comprehension to Students with Learning Difficulties.The Guildford Press. New York.

Moreillon,J. (2007). Collaborative Strategies for Teaching Reading Comprehension.Chicago: American Library Association.

Najmatul Fahli. (2015). An Analysis of the Students' Ability in Comprehending Recount Text at the Second Grade of SMP Muhammadiyah 1 Pekanbaru.

Surakhmad,W.(1994).Pengantar Penelitian ilmiah dan dasar metode teknik.Bandung:Transito.

Thesis. Faculty of Teacher Training and Education. Riau Univeristy.

Thesis. Faculty of Teachers Training and Education. Riau University.

Walker, J. B. (2000). Diagnostic Teaching of Reading: Techniques for Instruction and Assessment. 4th Ed. OH. Merril

Yuliana . (2018). A Study on Reading Comprehension of Recount Text at the Second Grade of SMP An Nur Pekan Baru. 